\title{
Resistance of Grapevine Cultivars to Meloidogyne hapla under Polyhouse Condition
}

\author{
T.H. Askary ${ }^{1^{*}}$, A. Khalil ${ }^{2}$ and N. Nazir ${ }^{2}$ \\ ${ }^{1}$ Division of Entomology, ${ }^{2}$ Division of Fruit Sciences, Sher-e-Kashmir University of \\ Agricultural Sciences and Technology, Main Campus, Shalimar, Srinagar-190025, \\ Jammu and Kashmir, India \\ *Corresponding author
}

\section{Keywords}

Grapevine,

Meloidogyne hapla, Nematode, cultivar, Polyhouse

\section{Article Info}

\section{Accepted:}

12 July 2018

Available Online:

10 August 2018

\section{A B S T R A C T}

A study was carried out to evaluate ten grapevine cultivars against root-knot nematode Meloidogyne hapla under polyhouse condition. The cultivars showed varying degree of susceptibility against nematodes in relation to nematode infestation and plant growth parameters. None of the grapevine cultivars used in the study was found to be highly resistant or resistant against M. hapla. Gall index was maximum in cultivar Pusa Navroz (4.8) followed by Sahebi (4.6), Hussaini (4.5) and Thompson seedless (4.0) and they were categorized susceptible to M. hapla. Tas-e-Ganesh and Manjri Naveen each with gall index 3.8 were moderately susceptible whereas, Fantasy 4 seedless was with least gall index (2.3) followed by K.R. White (2.5) and Kishmishi (2.6) and categorized as moderately resistant cultivars. Egg mass per root system was recorded maximum on Pusa Navroz (92.0) followed by Sahebi (87.66). Minimum egg masses were found on Fantasy 4 seedless (7.16) closely followed by K.R. White (8.66) and Kishmishi (8.83). Eggs per egg mass were found maximum in case of susceptible (223-290), followed by moderately susceptible (125-215) and moderately resistant cultivars (34-37). All the grapevine cultivars supported the multiplication of nematodes evidenced by a significant increase in the soil population of $M$. hapla $(P \leq 0.05)$. The cultivars supporting nematode multiplication in decreasing order was Pusa Navroz $>$ Sahebi $>$ Hussaini $>$ Thompson seedless $>$ Tas-e-Ganesh $>$ Manjri Naveen $>$ Red Globe $>$ Fantasy 4 seedless $>$ K.R. White $>$ Kishmishi. A significant decrease $(P \leq 0.05)$ in fresh and dry shoot weight as well as fresh and dry root weight was observed, however they varied with respect to susceptible, moderately susceptible and moderately resistant cultivars. Maximum reduction in fresh and shoot weight was recorded in Pusa Navroz (31.94 and $41.26 \%$, respectively) and minimum in Fantasy 4 seedless (10.43 and 14.06\%, respectively). Maximum reduction in fresh and dry root weight was recorded in Pusa Navroz (50.15 and 53.54\%, respectively) and minimum in Fantasy 4 seedless (25.94 and 25.90\%, respectively).

\section{Introduction}

Grapes (Vitis spp.) belonging to family Vitaceae is a commercially important fruit crop. It is native to Asia Minor and the Caucasus region, was distributed throughout Europe, and is now extensively grown in the Mediterranean Basin, the subtropical regions 
of Australia, Southern Africa, and North and South America (Brown et al., 1993). Most grapes come from cultivars of Vitis vinifera, and the major grape producing countries are China, USA, Italy, France, Spain and Turkey. Though, India ranks first in grape productivity (25.4 ton/ ha), followed by USA (18.7 ton/ ha) (Kumar, 2007), pests and diseases remain major constrain and problem in grape production. Among them, plant parasitic nematodes pose a continuous threat to fruit crop production as they cause serious damage to many horticultural crops (Askary and Haidar, 2010). The overall average annual yield loss of the world's major horticultural crops due to damage caused by plant parasitic nematodes has been estimated $13.54 \%$ (Parvatha Reddy, 2008). Several workers have reported the susceptibility of grapevine rootstocks to the economically important plant parasitic nematodes (Howland et al., 2014) and the annual losses in grape yield due to nematodes have been estimated $12.5 \%$ (Sasser and Freckman, 1987). Among the nematodes, Meloidogyne hapla are endo- parasites of grape roots that are responsible for debilitating the plant health and ultimately leading to qualitative and quantitive losses to grape production. Since this nematode species is prevalent in Kashmir valley, the evaluation of grape rootstocks under local condition is essential. Therefore, the present study was undertaken in polyhouse to assess the reaction of M. hapla against ten grapevine cultivars.

\section{Materials and Methods}

\section{Isolation, identification and mass culture of root-knot nematode, Meloidogyne hapla}

The population of root-knot nematode, $M$. hapla (Chitwood, 1949) was raised from egg masses, which were collected from eggplants grown in a pure culture bed. Large numbers of egg masses were excised with the help of sterilized forceps from the galled roots. Identification of nematode was done by preparing perineal patterns of 10 adult female nematodes per root system (Barker, 1985). The egg masses, after being washed in distilled water, were placed on a sieve layered with tissue paper for hatching at room temperature $22-25^{\circ} \mathrm{C}$. The sieve was placed over a funnel containing water to a level touching bottom of the sieve. A series of such assemblies were maintained to obtain large number of second stage juveniles required for inoculations. After every 24 hours, the juvenile suspension was collected from the funnel in a plate and thereafter, fresh water was added to the funnel till five days. The nematode suspension was collected from the plates and the second stage juveniles $\left(\mathrm{J}_{2}\right)$ of $M$. hapla were counted in a counting dish under stereoscopic microscope and the concentration $\mathrm{J}_{2}$ was standardized.

\section{Transplantation of grape cultivars and} nematode inoculation

Rooted cuttings of ten grapevine cultivars viz., Red Globe, K.R. White, Fantasy 4 seedless, Manjri Naveen, Hussaini, Pusa Navroz, Tas-e-Ganesh, Sahebi, Kishmishi and Thompson Seedless obtained from Division of Fruit Sciences, SKUAST-K, Srinagar were raised in sterilized soil and transplanted in 15 $\mathrm{cm}$ earthen pot filled with $1 \mathrm{~kg}$ autoclaved soil (field soil + compost 3:1). A day before transplantation $4 \mathrm{ml}$ nematode suspension containing $1000 \mathrm{M}$. hapla $\mathrm{J}_{2}$ was mixed in the top soil layer in each pot so that juveniles could distribute uniformly in the soil. For each cultivar a pot not inoculated with nematodes was used as a 'control' treatment for comparison. Six replicate pots for each treatment were used in the experiment and one plant was maintained in each pot. The pots were arranged in a completely randomized block design and kept in polyhouse condition. 


\section{Counting of galls and egg masses}

After 45 days plant from the pots were uprooted for recording galls and egg masses production on root system. Uprooting was done very carefully to prevent the damage to the root system. Root system of the uprooted plants was gently washed in slow stream of water to remove soil debris. The roots were visually observed to count galls and egg massers. To count egg masses, roots were treated with phloxine B solution $(0.159 \mathrm{~g} / \mathrm{l})$ which gave stain to egg masses.

\section{Categorization of grape cultivars for} nematode resistance

The grape cultivars were categorized for relative resistance or susceptibility by the degree of $M$. hapla infection. Number of galls/ root system was arranged accordingly on rating scale given by Taylor and Sasser (1978) (Table 1).

\section{Fresh/Dry weight of shoot and root system}

After uprooting the plant, weight of fresh shoot was recorded. The roots were washed thoroughly to remove soil debris and then dried and weighed. Shoot and root were then kept in the oven at $70{ }^{\circ} \mathrm{C}$ for 72 hours and after that taken out from the oven and weighed with the help of electronic balance.

\section{Soil population of root-knot nematode,} Meloidogyne hapla

Population of root-knot nematode, M. hapla was determined using Cobb's decanting and sieving method (modified) followed by Baermann funnel technique (Southey, 1986). Soil was mixed thoroughly and $250 \mathrm{~g}$ was taken from each pot. Soil sample was mixed in 2.5 litres of water in a plastic bucket. The soil-water mixture was stirred and then allowed to stand for 1-2 minutes. The suspension was decanted over a combination of 3 sieves $(60,200$ and 500 mesh), the catch from the finest sieve was carefully washed and transferred to a beaker.

A small coarse sieve with two layers of wet paper towels was kept in a Baermann funnel filled with water. The nematode suspension from the beaker was gently poured onto the sieve and allowed to stand overnight. The nematode juveniles because of the random and continuous movement migrate through the paper pores into the water and gradually settle down in the bottom of rubber tube of the funnel. The nematode suspension recovered from the Baermann funnel was taken into a beaker. The counting of nematode was performed in a counting dish under stereoscopic microscope with the help of hand tally counter.

\section{Statistical analysis}

Observations taken from the pots were averaged to calculate means. The data were analyzed by one way, single factor analysis of variance (ANOVA) and least significance difference (LSD) was calculated using Minitab 7.0 to identify significant effect of a treatment at probability levels of $P \leq 0.05$ per cent variation over control was also calculated.

\section{Results and Discussion}

\section{Galls and egg masses}

All the cultivars used in the experiment showed development of galls on their root system and they were categorized on the basis of root gall index (Table 2). The results revealed that none of the grapevine cultivars was highly resistant or resistant against the root-knot nematode, $M$. hapla. However, least gall index was found in case of Fantasy 4 seedless (2.3) followed by K.R. White (2.5) 
and Kishmishi (2.6) and these three cultivars were categorized as moderately resistant cultivars. The cultivars viz., Hussaini, Pusa Navroz, Sahebi and Thompson seedless were found susceptible to M. hapla. Gall index was maximum in Pusa Navroz (4.8) followed by Sahebi (4.6), Hussaini (4.5) and Thompson seedless (4.0). Tas-e-Ganesh and Manjri Naveen each with gall index 3.8 were moderately susceptible. The variations in the severity of gall formation in different grapevine cultivars may be due to the penetration and subsequent stabilization of $M$. hapla juveniles into the plant root system. The resistance and susceptibility to root-knot nematode are often expressed phenotypically and the formation of galls over the roots of the susceptible cultivar is the primary symptom of root-knot nematode infection. The present findings indicating the resistance or susceptibility of cultivars to M. hapla is on the basis of presence or absence of galls on roots of grapevine cultivars. Such report has also been confirmed by other workers (Téliz et al., 2007; Ferris et al., 2012).

Egg masses per root system were found highest in the grapevine cultivars categorized as susceptible to $M$. hapla (Table 2). It was maximum on Pusa Navroz (92.0) followed by
Sahebi (87.66). Similarly, eggs per egg mass were found maximum (222.83-290.0) on susceptible cultivars followed by moderately susceptible (124.50-215.33) and moderately resistant cultivars (33.50-37.0). Presence of highest number of egg masses confirms that maximum number of juveniles penetrated the roots and completed their life cycle in a successful manner. Minimum egg masses were found on Fantasy 4 seedless (7.16) closely followed by K.R. White (8.66) and Kishmishi (8.83). Few or poor number of egg masses indicates the resistance of cultivars against root-knot nematode as compared to susceptible ones (Cousins and Walker, 2000).

\section{Soil population of Meloidogyne hapla}

Grapevine cultivars supported the multiplication of nematodes evidenced by a significant increase in the soil population of M. hapla $(P \leq 0.05)$, being highest on the cultivar Pusa Navroz (1964), followed by Sahebi > Hussaini > Thompson seedless > Tas-e-Ganesh > Manjri Naveen > Red Globe over initial population. Relatively lesser increase in the soil population of $M$. hapla was noticed on Fantasy 4 seedless (215) followed by K.R. White > Kishmishi (Table 2).

Table.1 Root gall index Scale given by Taylor and Sasser (1978)

\begin{tabular}{|c|c|c|}
\hline No. of galls/root system & Root gall index (RGI) & Resistance rating \\
\hline $\mathbf{0}$ & 0 & Highly resistant or immune \\
\hline $\mathbf{1 - 2}$ & 1 & Resistant \\
\hline $\mathbf{1 1 - 3 0}$ & 2 & Moderately resistant \\
\hline $\mathbf{3 1 - 1 0 0}$ & 3 & Moderately susceptible \\
\hline $\mathbf{1 0 0}$ & 4 & Susceptible \\
\hline & 5 & Highly susceptible \\
\hline
\end{tabular}


Table.2 Development of galls, egg masses, eggs/ egg mass and soil population of root-knot nematode, Meloidogyne hapla in the rhizosphere of grapevine cultivars

\begin{tabular}{|c|c|c|c|c|c|c|}
\hline $\begin{array}{l}\text { Grape } \\
\text { cultivars }\end{array}$ & Treatment & $\begin{array}{l}\text { Egg } \\
\text { masses/ } \\
\text { root } \\
\text { system }\end{array}$ & $\begin{array}{l}\text { Eggs/egg } \\
\text { mass }\end{array}$ & $\begin{array}{l}\text { Nematode } \\
\text { population } / 250 \\
\text { g soil }\end{array}$ & $\begin{array}{l}\text { Root } \\
\text { gall } \\
\text { index }\end{array}$ & Reaction \\
\hline \multirow[t]{2}{*}{ Red Globe } & Control & --- & --- & --- & --- & \\
\hline & Inoculated & $40.50^{\mathrm{cd}}$ & $124.50^{\mathrm{de}}$ & $780^{\text {det }}$ & $3.5^{\mathrm{de}}$ & $\begin{array}{l}\text { Moderately } \\
\text { susceptible }\end{array}$ \\
\hline \multirow{2}{*}{$\begin{array}{l}\text { K.R. } \\
\text { White }\end{array}$} & Control & --- & --- & --- & --- & \\
\hline & Inoculated & $8.66^{\mathrm{de}}$ & $34.50^{\mathrm{ef}}$ & $285^{\mathrm{ef}}$ & $2.5^{\mathrm{ef}}$ & Moderately resistant \\
\hline \multirow{2}{*}{$\begin{array}{l}\text { Fantasy } 4 \\
\text { seedless }\end{array}$} & Control & --- & --- & --- & --- & \\
\hline & Inoculated & $7.16^{\mathrm{de}}$ & $33.50^{\text {ef }}$ & $215^{\mathrm{fg}}$ & $2.3^{\text {efg }}$ & Moderately resistant \\
\hline \multirow{2}{*}{$\begin{array}{l}\text { Manjri } \\
\text { Naveen }\end{array}$} & Control & --- & --- & --- & --- & \\
\hline & Inoculated & $50.83^{\mathrm{cd}}$ & $176.66^{\mathrm{d}}$ & $983^{\mathrm{de}}$ & $3.8^{\mathrm{cd}}$ & $\begin{array}{l}\text { Moderately } \\
\text { susceptible }\end{array}$ \\
\hline \multirow[t]{2}{*}{ Hussaini } & Control & --- & --- & --- & --- & \\
\hline & Inoculated & $83.16^{\mathrm{ab}}$ & $276.16^{c}$ & $1726^{\mathrm{c}}$ & $4.5^{\mathrm{ab}}$ & Susceptible \\
\hline \multirow{2}{*}{$\begin{array}{l}\text { Pusa } \\
\text { Navroz }\end{array}$} & Control & --- & --- & --- & --- & \\
\hline & Inoculated & $92.0^{\mathrm{a}}$ & $290.00^{\mathrm{a}}$ & $1964^{\mathrm{a}}$ & $4.8^{\mathrm{a}}$ & Susceptible \\
\hline \multirow{2}{*}{$\begin{array}{l}\text { Tas-e- } \\
\text { Ganesh }\end{array}$} & Control & --- & --- & --- & --- & \\
\hline & Inoculated & $62.16^{\mathrm{bc}}$ & $215.33^{\mathrm{cd}}$ & $1020^{\text {de }}$ & $3.8^{\mathrm{cd}}$ & $\begin{array}{l}\text { Moderately } \\
\text { susceptible }\end{array}$ \\
\hline \multirow[t]{2}{*}{ Sahebi } & Control & --- & --- & --- & --- & \\
\hline & Inoculated & $87.66^{\mathrm{ab}}$ & $285.33^{b}$ & $1908^{b}$ & $4.6^{\mathrm{ab}}$ & Susceptible \\
\hline \multirow[t]{2}{*}{ Kishmishi } & Control & --- & --- & --- & --- & \\
\hline & Inoculated & $8.83^{\mathrm{de}}$ & $37.0^{\text {ef }}$ & $332^{\text {ef }}$ & $2.6^{\mathrm{ef}}$ & Moderately resistant \\
\hline \multirow{2}{*}{$\begin{array}{l}\text { Thompson } \\
\text { Seedless }\end{array}$} & Control & --- & --- & --- & --- & \\
\hline & Inoculated & $65.50^{\mathrm{bc}}$ & $222.83^{\mathrm{cd}}$ & $1444^{\mathrm{d}}$ & $4.0^{c}$ & Susceptible \\
\hline
\end{tabular}

Each value is mean of six replications. Values in each column with different letters indicate significant differences according to Duncan's Multiple Range Test at $P \leq 0.05$. Values with same letters do not differ significantly. 
Table.3 Effect of $1000 \mathrm{~J}_{2}$ inoculum level of Meloidogyne hapla/ $\mathrm{kg}$ soil on fresh and dry shoot weight of different grapevine cultivars

\begin{tabular}{|c|c|c|c|c|}
\hline \multirow[t]{2}{*}{ Cultivars } & \multicolumn{2}{|c|}{ Fresh shoot weight (g) } & \multicolumn{2}{|c|}{ Dry shoot weight (g) } \\
\hline & Control & $\begin{array}{l}\text { M. hapla } \\
\left(1000 \mathrm{~J}_{2} / \mathrm{kg} \text { soil }\right)\end{array}$ & Control & $\begin{array}{l}\text { M. hapla } \\
\left(1000 \mathrm{~J}_{2} / \mathrm{kg} \text { soil }\right)\end{array}$ \\
\hline Red Globe & $39.66^{\mathrm{e}}$ & $\begin{array}{l}32.16^{\mathrm{bc}} \\
(-18.91)\end{array}$ & $8.23^{\mathrm{f}}$ & $\begin{array}{l}6.50^{\mathrm{de}} \\
(-21.02)\end{array}$ \\
\hline K.R. White & $44.20^{c}$ & $\begin{array}{l}38.00^{\mathrm{ab}} \\
(-14.02)\end{array}$ & $10.30^{\mathrm{cd}}$ & $\begin{array}{l}8.44^{\mathrm{c}} \\
(-18.05)\end{array}$ \\
\hline Fantasy 4 seedless & $50.80^{\mathrm{a}}$ & $\begin{array}{l}45.50^{a} \\
(-10.43)\end{array}$ & $11.23^{\mathrm{a}}$ & $\begin{array}{l}9.65^{\mathrm{a}} \\
(-14.06)\end{array}$ \\
\hline Manjri Naveen & $41.05^{\mathrm{bcd}}$ & $\begin{array}{l}31.50^{b c} \\
(-24.48)\end{array}$ & $9.74^{\text {cde }}$ & $\begin{array}{l}7.27^{\mathrm{d}} \\
(-25.35)\end{array}$ \\
\hline Hussaini & $41.02^{b c d}$ & $\begin{array}{l}28.83^{\mathrm{cd}} \\
(-29.71)\end{array}$ & $9.44^{\mathrm{de}}$ & $\begin{array}{l}6.14^{\mathrm{def}} \\
(-34.95)\end{array}$ \\
\hline Pusa Navroz & $41.38^{b c d}$ & $\begin{array}{l}28.16^{\mathrm{cd}} \\
(-31.94)\end{array}$ & $9.16^{\mathrm{de}}$ & $\begin{array}{l}5.38^{\mathrm{h}} \\
(-41.26)\end{array}$ \\
\hline Tas-e-Ganesh & $40.95^{d}$ & $\begin{array}{l}30.60^{b c} \\
(-25.27)\end{array}$ & $9.22^{\mathrm{de}}$ & $\begin{array}{l}6.56^{\text {det }} \\
(-28.63)\end{array}$ \\
\hline Sahebi & $40.84^{d}$ & $\begin{array}{l}28.33^{\mathrm{cd}} \\
(-30.63)\end{array}$ & $9.27^{\text {de }}$ & $\begin{array}{l}5.73^{g} \\
(-38.18)\end{array}$ \\
\hline Kishmishi & $47.00^{\mathrm{ab}}$ & $\begin{array}{l}39.13^{a b} \\
(-16.74)\end{array}$ & $11.05^{b c}$ & $\begin{array}{l}9.05^{b} \\
(-18.09)\end{array}$ \\
\hline Thompson Seedless & $42.10^{\text {bcd }}$ & $\begin{array}{l}30.33^{b c} \\
(-27.95)\end{array}$ & $9.35^{\mathrm{de}}$ & $\begin{array}{l}6.24^{\text {def }} \\
(-33.26)\end{array}$ \\
\hline $\mathrm{CD} P \leq 0.05$ & 4.09 & 3.12 & 0.39 & 0.24 \\
\hline$F$-value & NS & $9.24 * *$ & $4.56 * *$ & $23.31 * *$ \\
\hline
\end{tabular}

Each value is mean of six replications. Figures in parenthesis are percent decrease (-) over control. Values in each column with different letters indicate significant differences according to Duncan's Multiple Range Test at $P \leq 0.05$. Values with same letters do not differ significantly. $* *$ Significant at $P \leq 0.05$. NS $=$ Not significant at $P \leq 0.05$. 
Table.4 Effect of $1000 \mathrm{~J}_{2}$ inoculum level of Meloidogyne hapla/ kg soil on fresh and dry root weight of different grapevine cultivars

\begin{tabular}{|c|c|c|c|c|}
\hline \multirow[t]{2}{*}{ Cultivars } & \multicolumn{2}{|c|}{ Fresh root weight (g) } & \multicolumn{2}{|r|}{ Dry root weight (g) } \\
\hline & Control & $\begin{array}{c}\text { M. hapla } \\
\left(\mathbf{1 0 0 0} \mathrm{J}_{2} / \mathrm{kg} \text { soil }\right)\end{array}$ & Control & $\begin{array}{c}\text { M. hapla } \\
\text { (1000 } \mathrm{J}_{2} / \mathrm{kg} \text { soil) }\end{array}$ \\
\hline Red Globe & $21.42^{b c}$ & $\begin{array}{l}14.39^{d} \\
(-32.81)\end{array}$ & $5.60^{\mathrm{ab}}$ & $\begin{array}{l}3.70^{\mathrm{bc}} \\
(-33.92)\end{array}$ \\
\hline K.R. White & $22.26^{\mathrm{a}}$ & $\begin{array}{l}15.76^{b} \\
(-29.20)\end{array}$ & $5.63^{\mathrm{ab}}$ & $\begin{array}{l}4.05^{b} \\
(-28.06)\end{array}$ \\
\hline Fantasy 4 seedless & $21.51^{b c}$ & $\begin{array}{l}15.93^{\mathrm{a}} \\
(-25.94)\end{array}$ & $5.79^{\mathrm{a}}$ & $\begin{array}{l}4.29^{a} \\
(-25.90)\end{array}$ \\
\hline Manjri Naveen & $21.60^{b c}$ & $\begin{array}{l}14.15^{d} \\
(-34.49)\end{array}$ & $4.92^{\text {cd }}$ & $\begin{array}{l}2.92^{c} \\
(-40.65)\end{array}$ \\
\hline Hussaini & $20.40^{\mathrm{de}}$ & $\begin{array}{l}11.75^{f} \\
(-42.40)\end{array}$ & $5.00^{\mathrm{cd}}$ & $\begin{array}{l}2.60^{\mathrm{e}} \\
(-48.0)\end{array}$ \\
\hline Pusa Navroz & $19.82^{f}$ & $\begin{array}{l}9.88^{h} \\
(-50.15)\end{array}$ & $5.08^{c}$ & $\begin{array}{l}2.36^{\mathrm{f}} \\
(-53.54)\end{array}$ \\
\hline Tas-e-Ganesh & $20.45^{\mathrm{d}}$ & $\begin{array}{l}12.68^{\mathrm{e}} \\
(-37.99)\end{array}$ & $4.94^{\mathrm{cd}}$ & $\begin{array}{l}2.86^{\mathrm{c}} \\
(-42.10)\end{array}$ \\
\hline Sahebi & $20.24^{\mathrm{e}}$ & $\begin{array}{l}11.16^{g} \\
(-44.86)\end{array}$ & $5.08^{c}$ & $\begin{array}{l}2.58^{\mathrm{e}} \\
(49.21)\end{array}$ \\
\hline Kishmishi & $21.93^{b}$ & $\begin{array}{l}15.23^{c} \\
(-30.55)\end{array}$ & $5.47^{\mathrm{b}}$ & $\begin{array}{l}3.84^{b c} \\
(-29.79)\end{array}$ \\
\hline Thompson Seedless & $20.47^{\mathrm{d}}$ & $\begin{array}{l}12.32^{\mathrm{e}} \\
(-39.81)\end{array}$ & $4.99^{\mathrm{cd}}$ & $\begin{array}{l}2.75^{d} \\
(-44.88)\end{array}$ \\
\hline $\mathrm{CD} P \leq \mathbf{0 . 0 5}$ & 1.90 & 0.21 & 0.54 & 0.20 \\
\hline$F$-value & NS & $33.98 * *$ & NS & $12.97 * *$ \\
\hline
\end{tabular}

Each value is mean of six replications. Figures in parenthesis are percent decrease (-) over control. Values in each column with different letters indicate significant differences according to Duncan's Multiple Range Test at $P \leq 0.05$. Values with same letters do not differ significantly.

$* *$ Significant at $P \leq 0.05$. NS $=$ Not significant at $P \leq 0.05$.

\section{Plant growth}

All 10 cultivars of grapevine screened inoculated with $M$. hapla showed significant decrease $(P \leq 0.05)$ in fresh and dry shoot weight as well as fresh and dry root weight, however they varied with respect to susceptible, moderately susceptible and moderately resistant cultivars. Maximum reduction in fresh shoot weight was recorded in Pusa Navroz (31.94\%) followed by Sahebi (30.63\%) and Hussaini $(29.71 \%)$ whereas it was minimum in Fantasy 4 seedless $(10.43 \%)$, K.R. White $(14.02 \%)$ and The increased soil population of root-knot nematodes and formation of large number of root galls might be due to penetration of a large number of nematodes favoured by the 
susceptible cultivar and finally stabilized them to form the giant cells. Contrary to this, resistance is associated to a reduced rate of nematode penetration and their subsequent development and egg formation. This resulted in a low nematode population density with the fact that a few nematodes could complete their life cycle (Huang, 1986; Mukhtar et al., 2017).

Kishmishi (16.74\%) as compared to uninoculated control (Table 3). Maximum reduction in dry shoot weight was recorded in Pusa Navroz (41.26\%) and minimum in Fantasy 4 seedless $(14.06 \%)$. The reduction in growth parameters may be attributed to mechanical injury caused to roots due to penetration and feeding by nematodes making the root system inefficient in absorbing adequate water and translocating it to the top of the plant. A similar trend was also noted with regard to fresh and dry root weight. In case of Pusa Navroz, maximum reduction in fresh and dry root weight was 50.15 and $53.54 \%$, respectively whereas, for the cultivar Fantasy 4 seedless it was minimum i.e. 25.94 and $25.90 \%$, respectively (Table 4). This evidence is supported by the hypothesis that root-knot nematode cause infection on plant roots and induces the formation of nurse cells and monitor larger displacement of photosynthates towards infected roots which also results in disruption of water and nutrients to other plant parts (Caveness and Ogunforowa, 1985; Di Vito et al., 2004).

On the basis of present investigation it can be concluded that all the grapevine cultivars used in the experiment supported the multiplication of root-knot nematode, Meloidogyne hapla. However, degree of pathogenicity varied and it was maximum in the cultivars Pusa Navroz, Hussaini, Sahebi and Thompson seedless, and minimum in Fantasy 4 seedless, K.R. White and Kishmishi. The moderately susceptible cultivars were Red Globe, Manjri Naveen and
Tas-e-Ganesh. Thus, the cultivars Fantasy 4 seedless, K.R. White and Kishmishi can be used for cultivation but further research programme is needed to develop new nematode resistant cultivars. The exploration of resistance in grapevine cultivars may be the most pronounced strategy for reducing the nematode damage and encouragement of disease-free and healthy grape production.

\section{Acknowledgements}

This research is supported in part by MIDH project running in the Division of Fruit Sciences, SKUAST-Kashmir, Srinagar, India. We are also thankful to Division of Entomology, SKUAST-Kashmir for providing laboratory facilities needed to conduct the research work.

\section{References}

Askary, T.H. and Haidar, M.G. (2010). Plant parasitic nematodes associated with forest nurseries. Indian J. Nematol. 40: 239-240.

Askary, T.H. and Martinelli, P.R.P. (2015). Biocontrol Agents of Phytonematodes. $\mathrm{CAB}$ International, Wallingford, UK, pp. 470.

Askary, T.H., Banday, S.A., Iqbal, U., Khan, A.A., Mir, M.M. and Waliullah, M.I.S. (2012). Plant parasitic nematode diversity in pome, stone and nut fruits. In: Lichtfouse, E. (ed.) Agroecology and Strategies for Climate Change. Springer, The Netherlands, pp. 237268.

Barkar, K.R. (1985). Nematode extractions and bioassays. In: An advanced Treatise on Meloidogyne. Methodology, Voll. II, North Carlonia KR Barker, CC Carter, JN Sasser (eds), North Carolinia State University Graphics, Raleigh. pp. 1935.

Brown, D.J.F., Dalmasso, A. and Trudgill, 
D.L. (1993). Nematode pests of soft fruits and vines.

In: Evans, K., Trudgill, D.L. and Webster, J.M. (eds.) Plant-Parasitic Nematodes in Temperate Agriculture. $\mathrm{CAB}$ International, Wallingford, UK, pp. 427-462.

Caveness, F.E. and Ogunforowa, A.O. (1985) Nematological studies worldwide. In: Cowpea research production and utilization. Singh S.R and Rachie, K.O. (eds) Wiley and Sons, Chichester, UK, pp. 273-285.

Cousins, P. and Walker, M.A. (2000) Improved techniques for evaluating root knot nematode

resistance in vitis root stocks. Acta Hortic. 528: 577-577. DOI:

10.17660/ActaHortic.2000.528.84.

Di Vito, M., Volvos, N. and Castillo, P. (2004). Host parasite relationship of Meloidogyne incognita on spinach. Plant Pathol. 253: 508-514. DOI: 10.1111/j.1365-3059.2004.01053.x.

Ferris, H., Zheng, L. and Walker, M.A. (2012) Resistance of grape rootstocks to plant parasitic nematodes. Journal of Nematology 44, 377-386.

Howland, A.D., Schreiner, R.P. and Zasada, I. (2014). Spatial distribution of plantparasitic nematodes in semi-arid Vitis vinifera vineyards in Washington. $J$. Nematol. 46: 321-330.

Huang, S.P. (1986) Penetration, development, reproduction, and sex ratio of Meloidogyne javanica in three carrot cultivars. J. Nematol. 18: 408-412.

Kumar, B. (2007). Indian Horticulture Database 2006. National Horticultural
Board, Gurgaon, Haryana, India, pp. 324.

Mukhtar, T., Arooj, M., Ashfaq, M. and Gulzar, A. (2017) Resistance evaluation and host status of selected green gram germplasm against Meloidogyne incognita. Crop Prot. 92: 198-202. DOI.10.1016/j.cropro.2016.10.004

Parvatha Reddy, P. (2008). Diseases of Horticultural Crops: nematode problems and their management. Scientific Publishers, Jodhpur, India, pp. 379.

Sasser, J.N. and Freckman, D.W. (1987). A world perspective on nematology: The role of the society. In: Veech, J.A. and Dickson, D.W. (eds.) Vistas on Nematology. Society of Nematologists, Hyattsville, Maryland, USA, pp. 7-14.

Southey, J.F. (1986). Laboratory Methods for Work with Plant and Soil Nematodes. Her Majesty's Stationary Office, London (GB).

Téliz, D., Landa, B.B., Rapoport, H.F., Pérez Camacho, F., Jiménez-Díaz, R.M. and Castillo, P. (2007) Plant parasitic nematodes infecting grapevine in southern Spain and susceptible reaction to root-knot nematodes of rootstocks reported as moderately resistant. Plant Disease 91: 1147-1154.

Taylor, A.L. and Sasser, J.N. (1978). Biology, identification and control of root-knot nematodes

(Meloidogyne spp.). Co-op. Publication Department Plant Pathology, North Carolina State University and U.S. Agency Int. Dev. Raleigh, North Carolina, pp.

\section{How to cite this article:}

Askary, T.H., A. Khalil and Nazir, N. 2018. Resistance of Grapevine Cultivars to Meloidogyne hapla under Polyhouse Condition. Int.J.Curr.Microbiol.App.Sci. 7(08): 2351-2359. doi: https://doi.org/10.20546/ijcmas.2018.708.236 